\title{
フライス加工による残留応力*
}

\author{
村上 裕 則** 洲 弘 昭***
}

\section{Residual Stresses due to the Milling Operation}

by

\author{
Yasunori Murakami and Hiroaki Ibuchi \\ (Faculty of Science and Engineering, Ritsumeikan University, Kyoto)
}

\begin{abstract}
Residual stresses of considerable magnitude are generally introduced near the surface layers of machine components by the machining operation. These residual stresses are deleterious from the standpoint of precise finishing, and also have some effects on the fatigue strength. Therefore, the measurement of these stresses is an important subject for machine manufacturers. Several studies have been reported concerning the residual stresses produced by the machining operation, such as turning, shapering, milling and grinding etc. $\left.{ }^{1}{ }^{-3}\right)$

In this study, the surface residual stresses due to the milling operation were measured with $\mathbf{X}$ rays under several conditions such as the cutting speed, the feeding and the depth of cut. Flat plate specimens of a low carbon steel and a high tensile strength steel were used, and one surface of the specimen was cut with a plain milling cutter of $25^{\circ}$ spiral angle under the cooling action of oil lubricant. The X-ray apparatus used was of parallel beam type with GM counter, and GoK $\alpha$ beams were used throughout this experiment. The residual stresses were measured by the $\sin ^{2} \psi$ method in the cutting direction as well as in the transverse direction. The distribution of residual stress near the surface was examined by etching off a thin layer successively from the machined surface and by utilizing the correction formula.4) The changes in the half-value breadth due to successive removal of surface layers and in hardness were also investigated.

The conclusions obtained in this study may be summarized as follows. The increase in the cutting speed has the effect of decreasing the tensile residual stress, on the contrary, the increase in the feeding exerts such influence as to raise the residual stress toward the tension side. On the other hand, the residual stress tends to maintain nearly a constant value despite of the increase in the depth of cut. The region of monotonous decrease in the half-value breadth and hardness which may be considered to represent the domain of deteriorated surface layers $\left.{ }^{\theta}\right)$, was in approximate coincidence with the range in which the residual stress distribution showed a remarkable change.
\end{abstract}

(Received Aug. 16, 1967)

\section{1 緒言}

切削加工によって一般に加工面に残留度力を生ずる が，これは精密茌上の観点からは有害無益である。ま た，切削加工された機栈部品が繰返し応力を受ける場 合には，残留応力心符号によって疲労強度にきまざま な影響を及ばすことが報告されている，したがって， 切削加工後の残留底力を澌定するととは，仕上精度方 よび度学強度を向上させる点から重要なととである.

従来, 旋盤加工, シェーパ加工, フライス加工, 研 削加工などの各種の切削加工による残留応力の測定結 果はかなり報告されてわり，いずれる表面層にかなり 高い引倨りまたは区縮の残留芯力が見いだされている。 しかし，切削諸条件すなから切削速度，送りおよび切

* 原稿受理 图和42年8月16日

* 正会员 立命館大学理工学部 京都市北区等持睆北町

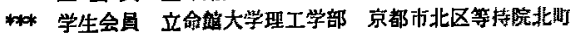

込みなどを系統的に変えて残留応力を測定した例は少 ない、シェーパ加工につては，乙兑ら諸条件を变元 て残留応力を $\mathbf{x}$ 線的に测定した報告があり，また，フ ライス加工においても送りのみを変化させて機械的方 法によって牫留応力を測定した例が見られる。 本実跧にわいては，フライス加工について，上記の 切削三条件を変えてX線的に残留心力を测定した。

\section{$2 \cdot 1$ 試験 片}

\section{2 実 験 方 法}

用いた誁馀片の形状はFig. 1 に示すとおりで, $150 \times$ $30 \mathrm{~mm}$ の面を片面切削した。試験片の材質はSS41 お

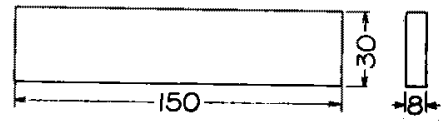

Fig. 1. Shape of specimen. 
Table I. Chemical compositions and mechanical properties of high tensile strength steel.

\begin{tabular}{c|c|c|c|c}
\hline $\mathrm{C}$ & $\mathrm{Si}$ & $\mathrm{Mn}$ & $\mathrm{P}$ & $\mathrm{S}$ \\
\hline 0.1 & 0.35 & 1.04 & 0.016 & 0.029 \\
\hline $\begin{array}{c}\text { Yield point } \\
\left(\mathrm{kg} / \mathrm{mm}^{2}\right)\end{array}$ & $\begin{array}{c}\text { Tensile strength } \\
\left(\mathrm{kg} / \mathrm{mm}^{2}\right)\end{array}$ & $\begin{array}{c}\text { Elongation } \\
(\%)\end{array}$ \\
\hline 43.4 & 59.0 & \multicolumn{2}{|c|}{30.2} \\
\hline
\end{tabular}

よび高張力鋼（中部鍮放の提供による）で，高張力鋼の 化学成分および機械的性筫を Table I 亿示す.

試験片は無応力状態にするために，650 $\mathrm{C}$ 低温焼 なまし(真空炉中)を 2 回行なった。 その結果の残留応 力は土 $1 \mathrm{~kg} / \mathrm{mm}^{2}$ 程度であった。なお，㜔なまし後の 結晶粒度を調べたが，両材質とも ASTM No. 8 の大 きさであった。

\section{$2 \cdot 2$ フライスの形状}

使用したフライスは材質 SKH2 で外径 $80 \mathrm{~mm}$ ，長さ $80 \mathrm{~mm}$ のねじれ刃平フライスで，ねじれ争 $25^{\circ}$ ，逃げ 角 $8^{\circ}$ または $12^{\circ}$ ，すくい角約 $2^{\circ}$ ，刃数18枚である.

\section{$2 \cdot 3$ 切刿条件}

使用したフライス盤は横フライス盤(遠州機諴製)で, 選択した切削条件の籍囲は Table II のようである.

Table II. Gutting conditions.

\begin{tabular}{l|c|c|c|c|c}
\hline Cutting speed (m/min) & 22.9 & 34.7 & 53.0 & 80.4 & - \\
Feed (mm/min) & 78 & 117 & 168 & 227 & 326 \\
Depth of cut (mm) & 0.2 & 0.4 & 0.6 & 0.8 & 1.0 \\
\hline
\end{tabular}

このうち切削速度の影望に閣しては，送り $117 \mathrm{~mm} /$ $\min$,切込み0.4 mmを一定とし, 送りの影響にいつて は切削速度 $22.9 \mathrm{~m} / \mathrm{min}$ ，切込み $0.4 \mathrm{~mm}$ を一定に保ち， また切込みの影監については，切削速度 $22.9 \mathrm{~m} / \mathrm{min}$, 送り $117 \mathrm{~mm} / \mathrm{min}$ 定一定に保って㬰験した，な机，切 削は上向き削りで行ない，切削中は鉱油を一定量 (1.5l min)注ぎながら湿切剧を行なった。

\section{$2 \cdot 4$ 表面あらさの則定}

切削加工面のあらさを調べるために，仙針式表面あ らさ測定機を用いて各切削条件のもとにおける表面あ らをを測定した，その中の二例をFig. 2 に示す.

図に兒られるように，送りが增すほど切削方河のウ エーブは大きくなっているが，切削直角方向のあらさ にははとんど差は見られない.

\subsection{X 線応力列定条件}

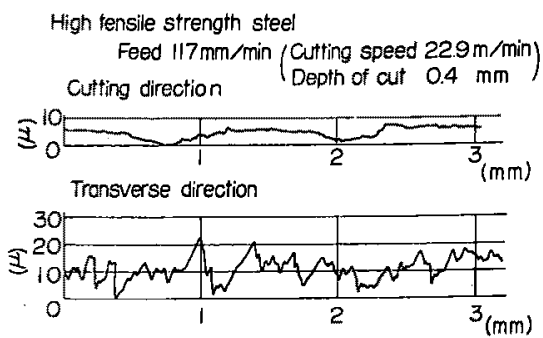

Feed $227 \mathrm{~mm} / \mathrm{min}$ (Cutting speed $22.9 \mathrm{~m} / \mathrm{min}$ )

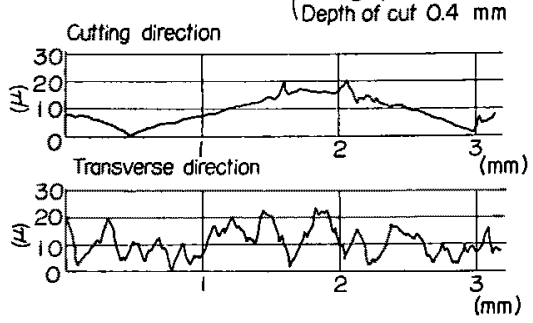

Fig. 2. Surface roughness.

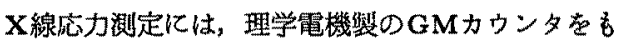
つ自動記録式平行ビーム型ひずみ测定装置を用いた。 測定は $\operatorname{Sin}^{2} \phi$ 法を用い，ピーク位琪の決定法には半侕 また湢法を用いた，測定条件は Table III にまとめて 示してある.

なお，馀跧片の切削方向および或折直角方向におけ る各点の残留応力の相遠を調べるために，Fig. 3 亿示 すように，切削方向に 5 点をとり，直角方向に 3 点を とって，ともに切削方向の残留応力を測定した，図に 見るように，いずれの方向においてもかなりのばらつ きを示した，したがって，照射面積 $10 \times 2.7 \mathrm{~mm}^{2}$ の中 心を試験片中心に合せて $(10 \mathrm{~mm}$ 長手方向にとった 長手方向に左右 $15 \mathrm{~mm}$ ずつ，30 $\mathrm{mm}$ のストロークで武 験片を往復運動させて，乙の間の平均线留忘力を測定 したが，その值は図に示した平均値とほぼ一致した。

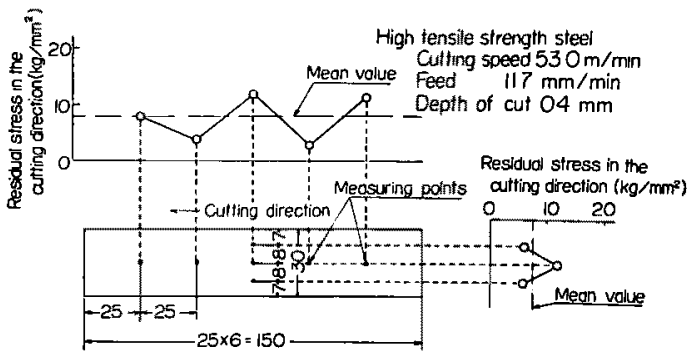

Fig. 3. Residual stresses at several points.

Table III. Measuring conditions.

\begin{tabular}{c|c|c|c|c}
\hline X-ray & $\begin{array}{c}\text { Tube voltage } \\
\text { and current }\end{array}$ & $\begin{array}{c}\text { Soller slit and } \\
\text { measuring area }\end{array}$ & Time constant & $\begin{array}{c}\text { Goniometer and } \\
\text { chart speed }\end{array}$ \\
\hline $\mathrm{CoK} \alpha$ & $\begin{array}{c}30 \mathrm{kVP} \\
9.5 \mathrm{~mA}\end{array}$ & $10 \times 2.7^{0.35^{\circ}}$ & $16 \mathrm{~s} \mathrm{~mm}^{\circ}$ & $10 \mathrm{~mm} / \mathrm{min}$ \\
\hline
\end{tabular}


したがって，以後の測定はすべてての方法で行なった。 ただし，実際に採用した往復運動の速度はやや小さか ったので，測定絬果としては満足すべき值が得られた が，真の平均的な残留応力を測定しえたかは疑問であ る. また，切削加工後の残留応力を安定させるために， 測定はすべて切削 2 日後に行なった。

\section{$2 \cdot 6$ 梁さ方向の残留応力の計算式}

深さ方向の牫留応力は，15\%硝酸浴液を用いて切削 面から逐次薄凰を㓏食し去り，そのつど切削面および 裏面の応力を $\mathrm{X}$ 線で測定して，次式を用いて計算し た.

Fig. 4 亿示すように，a圆まで腐食し去ると，モー

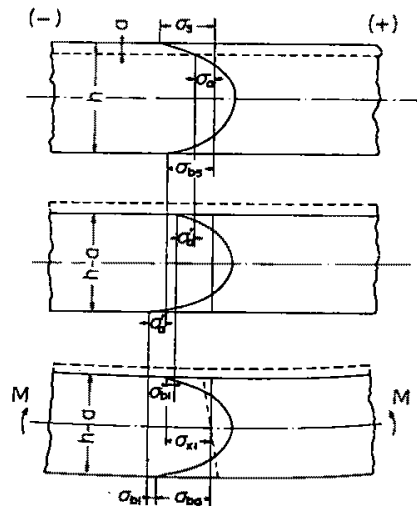

Fig. 4. Residual stress distribution due to etching.

メントのつりあいが破れて，Mなる曲げモーメントを

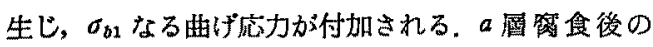
表面の応力 $\sigma_{X 1}$ は

$$
\sigma_{X 1}=\sigma_{a}+\sigma_{a}{ }^{\prime}+\sigma_{b 1}
$$

こてで, $\sigma_{a}$ : 食食の $a$ 層の応力

$\sigma_{a}{ }^{\prime}: a$ 層窟食炕上る解放応力

$\sigma_{a}{ }^{\prime}$ は次のように近似してょい。

$$
\sigma_{a}{ }^{\prime}=\frac{1}{h-a} \int_{0}^{a} \sigma d a \div \frac{1}{h-a} \cdot \frac{a}{2}\left(\sigma_{1}+\sigma_{a}\right)
$$

ここで， $\sigma_{s}:$ 䇠食前の表面の応力

$a$ 圈符食後の裹面の店力 $\sigma_{b a}$ は

$$
\sigma_{b u}=\sigma_{b s}+\sigma_{a}^{\prime}-\sigma_{b 1}
$$

ことで， $\sigma_{b t}:$ 窗食前の变面の応力

(3)式汃ら $\sigma_{b 1}=\sigma_{a}{ }^{\prime}+\left(\sigma_{b t}-\sigma_{b a}\right)$

これを(1)式へ代入して

$$
\begin{aligned}
& \sigma_{X 1}=\sigma_{a}+\sigma_{a}{ }^{\prime}+\sigma_{a}{ }^{\prime}+\left(\sigma_{b a}-\sigma_{b a}\right) . \\
& =\sigma_{a}+\frac{a}{h-a}\left(\sigma_{a}+\sigma_{a}\right)+\left(\sigma_{b a}-\sigma_{b a}\right)
\end{aligned}
$$

上式から $\sigma_{a}$ を求めると，最終的に次式が得られる.

$$
\sigma_{a}=\frac{h-a}{h}\left(\sigma_{x 1}-\frac{a}{h-a} \sigma_{b}-\left(\sigma_{b s}-\sigma_{b a}\right)\right)
$$

第 2 回窝食以後の計算式も同様導くことができる。

\section{3 実験結果およひ考察}

\section{$3 \cdot 1$ 切削速度の影翼}

切削速度による表面残留応力の変化をFig. 5 亿示す。

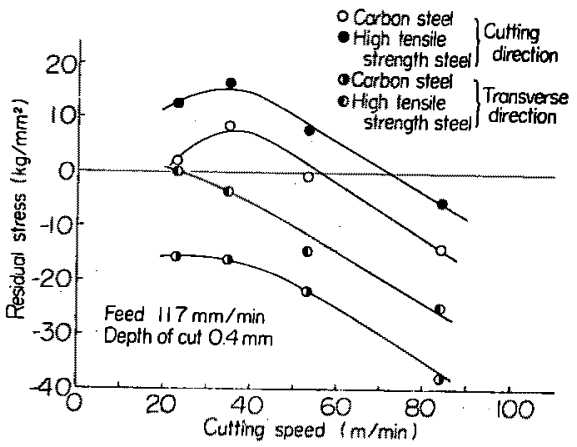

Fig. 5. Effect of cutting speed on residual stresses.

図において残留応力は炭素鋼，高張力鋼ともに切削方 向では，切削速度の小さい範围で引張りとして現われ ており, 切削速度が增すと引張りの值が減少して，圧 縮側に堌大する傾向がある．また，切削直角方向では， すべて王縮の值を示し, 切削速度の増加とともに上と 同し王縮側に増大する傾向を表わしている．

一般に，切削による臸留応力発生機構としては大別 して，切削作用による機械的勃果之熱的效果市洘光ら れる．前者をさら詳しく考察すると，切削点前方の 被削材は表面で最大で深さ方向に漸次诚少するかなり 大きな王縮応力を受けて，表面からある深さまで圧縮 望性変形を生ずる．との点は工具の通過後には引張応 力る受けるが，一般には㴼応力のほうがかなり大き いために切削加工後の表面に圧縮望性変形が残る. こ の結果，最後に引張残留応力を生ずるるのとされてい る. 次に，後者の熱的効果については，切削の摩擦作 用による温度上昇によって表面層が䚾縮望性変形を受 け，したがって加工後には引張残留茫力を生ずる。

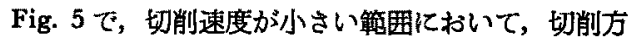
向の残留応力が引張りとして現われているととは，上 に述べた一般の㑯向と一致している，また，一般に切 削速度が增すと切削抵抗は減少主るが，被切削材内保 生する応力を考兄る場合には，比切削抵抗で考察する のが合理的である。いまの場合岆り，切込みは一 定であるだめ，比切削抵抗は切刷抵抗に正比例する。 したがって，切削速度が増加すると比切削抵抗は減少 して，工具前方の被削材が受ける圧縮応力が小さくな り, 逆に, 工具通過後の弓㖘応力が打古勝つととが考 光られる. この結果, 引張残留応力は, 切削速度が增 すに従って濑次減少し，つに压縮側に移行するとと がありうる，一方，切削面の温度は切削速度が増すほ ど增加するが，ての影響によっては残留応力は逆に引 
張側に增すはずである，しかし，実験結果は炀削速度 の增加とともに引張残留応力か诚少し，ある切削速度 上上では压縮残留応力が現われているので，前者の影 響が後者に比べて打ち勝ったものと思われる．本実駼 の傾向は文献2)のシェーパ加工の傾向と逆であるが， ての場合には，乾切削を行なっているため，熱的効果 のはうが大きく影響したものと思われる．次に，切削 直角方向の残留究力がすべて圧縮値を示したことにつ いては，次の上うに考えられる。すすなわち，フライス のねじれ角が25地あるため，ねじれ刃に垂直方向の 切削抵抗の切削直角方向への分力が小さく，したがっ $\tau$ ，切削点前方の被削材の受ける圧縮応力が小さくな り, 前に述べたのと同様の理由によって区縮の値を示 したものと思われる．切削速度の増加に偻ってての圧 縮応力はますます小さくなり，压縮残留応力の增加を もたらしたものと考えられる．切削抵抗の背分力も圧 縮残留応力を生ずる原因となるが，背分力は主分力に 比へててきわめて小さく，その影響は小さいるのと思わ れる，また，残留応力は高張力鎆よりる炭素鍴のはう が弓張側に小さく現われているが，てれは切削抵抗が かたさに正此例して减少するととによるものと思われ る.

\section{$3 \cdot 2$ 送りの影读}

Fig. 6 は送りの影整を示するので，残留底力はすべ

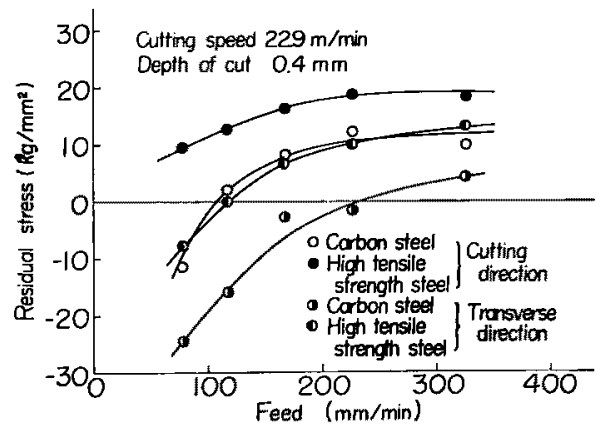

Fig. 6. Effect of feed on residual stresses.

て送りの增加に伴って弓張側に增す傾向を示している。 ての原因は次のように考えられる。すすなわ关送りを增 すと切削抵抗は注但比例的に增加するが，比切削抵抗 ははとんど一定(やや右下がりの㑯向を示す)であるか ら，この影響は考元られない，一方送りを增すと切削 面の温度は上昇するので, 湿切削ではあるが，乙の場 合にはこの温度上昇が残留応力を引張側に增加させた 主要な原因と考えられる。

なお，鋼種および測定方向の相違による残留応力の 傾向はFig. 5 と同樣である.

\section{$3 \cdot 3$ 切込みの影管}

Fig. 7 は切込みの影響を示するので, 残留应力は行 込みの增加ととるにやや娍少する傾向る見られるが，
総体的に言ってほほ一定とみなしてもよい。とれは比 切削抵抗が切込みが変化してもはとんど一定（やや右 下がりの傾向を示す）であり，また温度も切込みによ ってほとんど変化しないてとによって説明される。

なお，送りおよび切込みの影響に関しては，本実驗 結果はシェーパの乾切削の実験結果と同一の傾向を示 している.

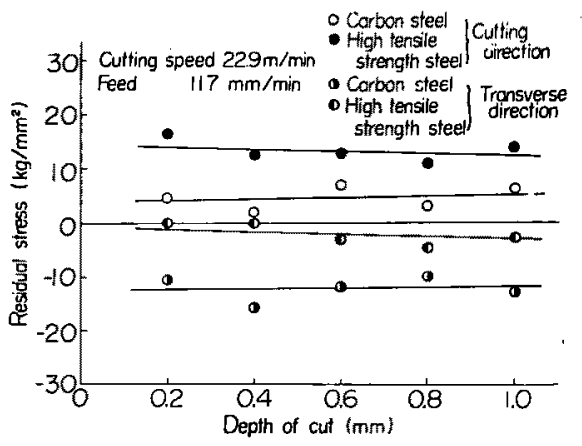

Fig. 7. Effect of the depth of cut on residual stresses.

\section{$3 \cdot 4$ 残留応力分布}

高張力鎦について厚さ方向の牫留视力分布を测定し た結果の一例をFig. 8 に示す. 図に見られるように, 切削方向の残留心力は，表面のすぐ内部で引張りのピ 一クを示し，炊いて死縮に変化している，てれに対し， 切削直角方向では，表面ではぼ零（てれはたまたまこ のような結果になったもので，Fig. 5 の切削速度 22.9 $\mathrm{m} / \mathrm{min}$ の点に相当する)で，そのすぐ内部で圧縮の最 大值を示し，その後渐次堿少している，切削方向，切 削直角方向ともに残留応力が大きな変化を示す範国は， 表面から約 $100 \mu$ の深さである．他の測定を通じてて

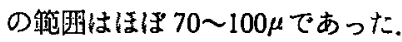

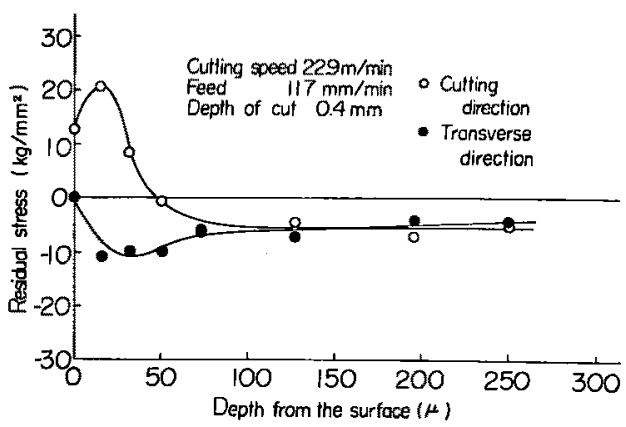

Fig. 8. Residual stress distribution near the surface.

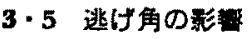

本奏駼は付随的に行なったもので，フライス䞍入初 期の逃げ角は約 $8^{\circ}$ で，てれを用いて炭素鋼の切削を行 ない，その後高張力鎆を切削する際これをとぎ直して 
逃げ角 $12^{\circ}$ とした．そしてての逃げ角 $12^{\circ}$ の状照でふた たび扊素鋼の切削范行なった，したがって，炭素銅に ついて逃げ角が残留応力に及ほ方影饗を調へててみた

Fig.9，10はこの結果を示すもので，それぞれ切削速

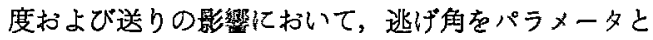
して示したるのである．両図に見られるように，残留 応力の変化の傾向は, 前に示したFig. 5, 6 と同樣で あるが，逃げ触の小さい初期のフライスで加工したは

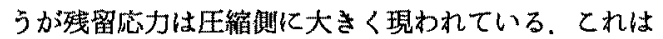
逃げ解が小さいために（おそらく刃先の鋭さす多少影 響したものと思われる，切削加工面のむしれがははは だしく，したがって面の凹凸が大き，切削点後方の 引張りの望性変形か残留応力を压縮側に増大させたも のと思わ机る。

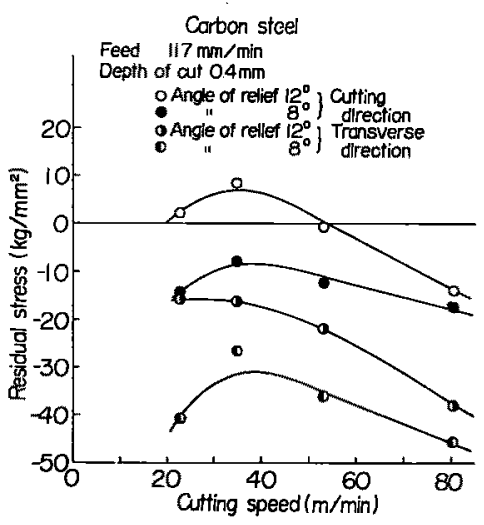

Fig. 9. Difference in residual stresses due to the angle of relief.

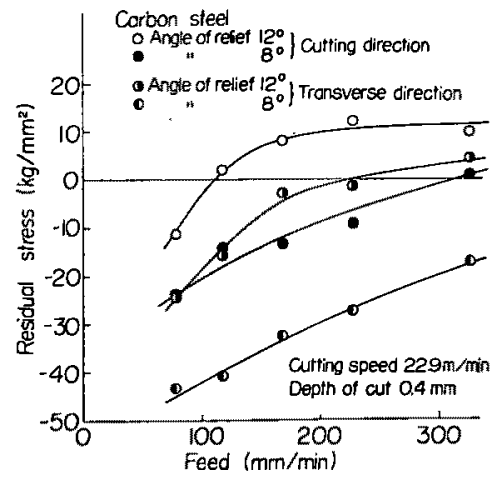

Fig. 10. Difference in residual stresses due to the angle of relief.

\section{6 加工变县雷の半価幅堌加率およひ硬化率}

一般に，切削加工面には切削作用の機械的効果によ

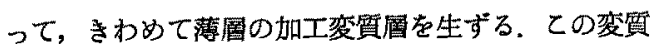

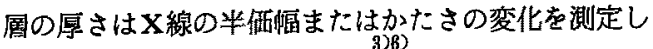
て，ほほ推定することができる.本实験においてもこ の両者を測定してみた，半価幅は表面から逐次溥圆を
15\%硝酸溶夜で简食しさり，そのつど垂直入射によっ て测定した。半価幅としては回折強度分布曲線の $1 / 2 \cdot H$ におるる稫をとった。功さは微小硬度計で荷重 200 gのもとで測定した．との測定は試験片の横断面上で 行なったもので，表面から $50 \mu の$ 深さの点から測定を 開炲した，Fig.11，12 はこの結果示するので，綎軸

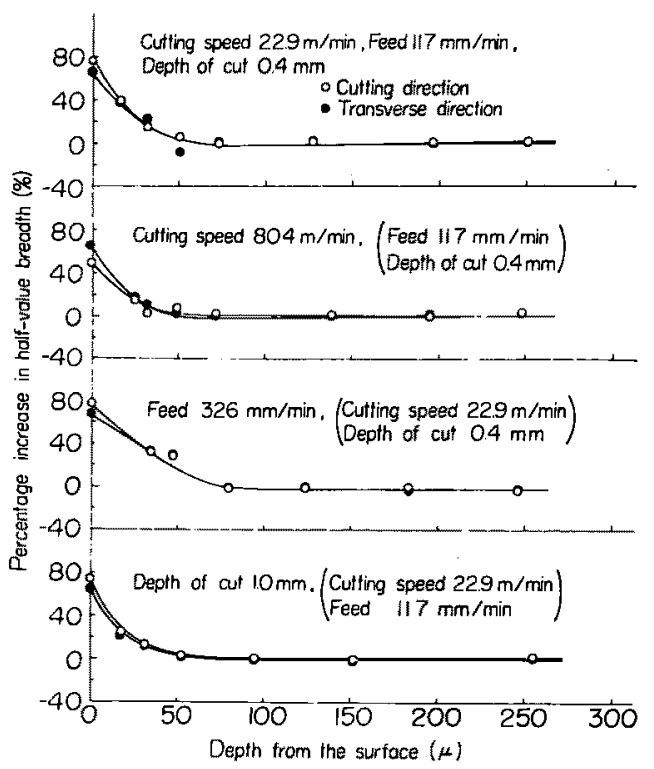

Fig. 11. Changes in half-value breadth near the surface.

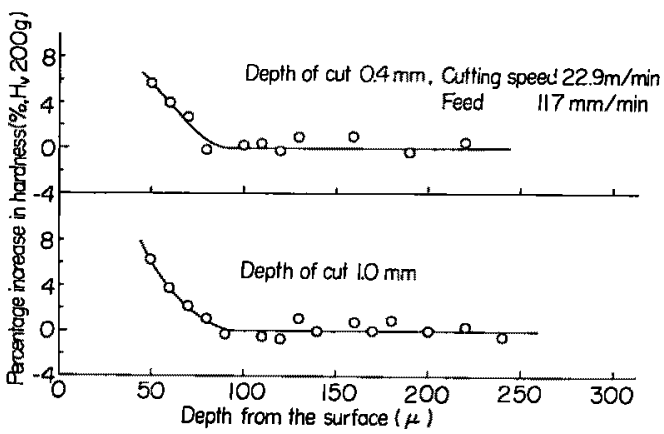

Fig. 12. Ghanges in hardness near the surface.

にはそれぞれ半価幅堌加率 $\left(B-B_{0} / B_{8}\right) \times 100 \%$, 硬化率 $\left(H_{V}-H_{V 0} / H_{V 0}\right) \times 100 \%\left(B_{0}, H_{V 0}\right.$ は初期值を示す $)$ を とった，Fig.11から，測定誤美も影響して正確には断 定できないが，㑯向としては加工変賀風の厚さは，切 削速度が增すと娍少し，送りまたは切込みを増すと増 加する様子が見られる。同様にFig.12汃らも，切込み が增すと加工変賈層の厚さは增加することがわかる。 两図を通じて本実験の籁国内で注，加工変質層の厚さ

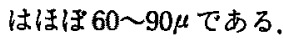

またこの筙围柱， 3 - 4項で述べた残留応力分布が大 きく変化する範囲之もはは一致している。 


\section{4 結}

論

以上の奖驗絬果をまとめて，次のような結諭が得ら れる。

（1）切削速度の影篦については，てれが增加するは ど引張残留応力を隇少させ，圧縮側に增加させる攧向 がある．ただし，切削直角方向の残留応力はすべて圧 縮として現われた，送りの影響については、てれが増

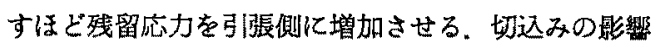
については，てれが增加してもはとんど残留灾力に影 幚を及ばさない。

（2）炭素鋼と高張力鎆とを比較すると, 残留応力は, 高張力鋼のほうが弓張側に高く現われる。

(3) 逃げ角が小さく,かつ刃先の摩耗したフライスで 削る場合，加工面のししれが箸しく，残留灾力は正縮 側に増加する傾向がある。
（4）半価愊增加率および硬化率で测定した加工変質 圆の推定厚さと残留応力分布が大きな変化を示す範囲 とはほは一致するものと言える。

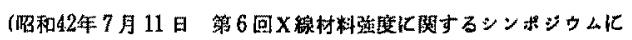
て蕂演)

\section{参 考 文 献}

1) Henriksen, E.K., Trans. ASME, 73, 69 (1951); Letner, H.R., Trans. ASME, 77, 1089 (1955); 古元隆生，神中進，日本金屈学会部，25，365 (1961).

2）石并勇五郎，日本機械学会䧻文笨，16，15(1950).

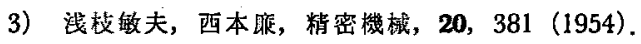

4）平修二, 吉岡靖夫，材料，11，675（1962）.

5) 佐田登志夫, 日機械学会諭文集, 25, 464(1959).

6）荒本由䇺，日本機械学会論文集，28，1361(1992). 